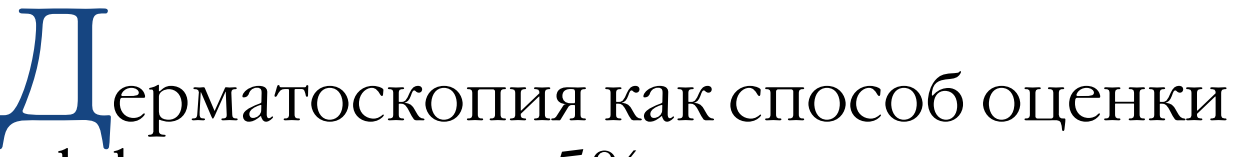 эффективности 5\% крема имиквимод у пациентов с базально-клеточной карциномой кожи
}

М. В. Жучков ${ }^{1,2}$, Д. Б. Сонин ${ }^{1}$, М. А. Тарасова ${ }^{1,2}$, С. А. Косорукова

1 ГБУ РО «Областной клинический кожно-венерологический диспансер» 390046, г. Рязань, ул. Спортивная, д. 9

${ }^{2}$ ФГБОУ ВО «Рязанский государственный медицинский университет имени академика И. П. Павлова» Минздрава России

390026, г. Рязань, ул. Высоковольтная, д. 9

Цель. Изучение возможностей дерматоскопии как метода оценки эффективности терапии топическим имиквимодом у пациентов с поверхностной базально-клеточной карциномой (БКК).

Материал и методы. В исследование были включены 24 пациента с поверхностной формой БКК, которым по различным причинам не было осуществлено эксцизионное хирургическое вмешательство, согласившиеся на альтернативную медикаментозную терапию (официнальный оригинальный топический имиквимод). Пациенты были разделены на две группы, в которых эффективность терапии оценивалась либо по клиническим, либо по дерматоскопическим признакам.

Основные результаты. В исследовании была продемонстрирована значимость дерматоскопии как метода оценки эсрфективности терапии топическим имиквимодом; большая прогностическая значимость дерматоскопии в сравнении с простым клиническим осмотром образования при оценке момента прекращения медикаментозной терапии имиквимодом.

Ключевые слова: базально-клеточная карцинома кожи, имиквимод, дерматоскопия.

Контактная информация: misha.juchkov@gmail.com. Вестник дерматологии и венерологии 2017; (3): 32—41. 


\title{
Sermatoscopy as a method of evaluating the efficiency of $5 \%$ cream imykvimod in patients with basal cell carcinoma of skin
}

\author{
M. V. Zhuchkov ${ }^{1,2}$, D. B. Sonin ${ }^{1}$, M. A. Tarasova ${ }^{1,2}$, S. A. Kosorukova ${ }^{2}$
}

${ }^{1}$ Ryazan Regional Clinical Skin and Venereal Diseases Dispensary

Sport str., 9, Ryazan, 390046, Russia

${ }^{2}$ Ryazan State Medical University

Vysokovoltnaya str., 9, Ryazan, 390026, Russia

The aim. Investigation of the possibilities of dermatoscopy as a method for evaluating the effectiveness of therapy with topical imiquimod in patients with superficial basal cell carcinoma (CCB).

Materials and methods. The study included 24 patients with a superficial form of CCB, who for various reasons did not undergo excisional surgical intervention and who agreed to alternative drug therapy (officinal original topical imiquimod). Patients were divided into two groups, in which the efficacy of therapy was assessed either by clinical or by dermatoscopic signs.

General results. The study demonstrated the importance of dermatoscopy as a method for assessing the effectiveness of therapy with topical imiquimod; Greater prognostic significance of dermatoscopy in comparison with a simple clinical examination of mass when assessing the moment of interruption of drug therapy with imiquimod.

Key words: basal cell carcinoma of skin, imiqiumod, dermatoscopy. 
Базально-клеточная карцинома (БКК) является в настоящее время наиболее распространенной эпителиальной злокачественной опухолью кожи [1]. Первое клиническое описание этого новообразования было сделано в 1872 г. известным дерматологом Jacob, обратившим внимание на быстропрогрессирующие язвенные дефекты области лица [2]. За более чем вековую историю изучения этой злокачественной опухоли кожи современная дерматоонкология достигла значительных успехов не только в понимании основных путей канцерогенеза при базалиоме (мутация р53, сигнальный путь Hedgehog и пр.), но и в применении различных способов лечения данного вида новообразования кожи [3]. В лечении БКК кожи применяется большое количество хирургических и терапевтических методов. Стандартная хирургическая эксцизия опухоли, к сожалению, на всей территории Российской Федерации продолжает оставаться наиболее популярным способом лечения базалиом кожи вне зависимости от ее клинической разновидности, локализации и наличия периневральной инвазии. Между тем при многих положительных моментах данного способа терапии (низкая стоимость, возможность гистологической верификации клинической формы заболевания и пр.) он не лишен недостатков, таких как высокая частота рецидивов при склеродермоподобной и рецидивирующей базалиоме, а также невозможность обеспечения принципа абластики при некоторых локализациях опухоли (область угла глаза и т.д.) [4].

Микрографическая эксцизия по методике Мохса как метод хирургической коррекции базалиом кожи уже много лет претендует на звание золотого стандарта лечебной тактики у данной категории пациентов [5]. Единственный фактор, сдерживающий широкое внедрение данного метода, - чрезвычайная техническая сложность его выполнения. Кюретаж, электрокоагуляция и криодеструкция очагов базалиомы в большом количестве клинических исследований продемонстрировали относительно высокую частоту рецидивов при их применении. Причем частота рецидивов БКК находилась в прямой корреляционной зависимости от размеров опухоли. Применение фотодинамической терапии ограничено толщиной базалиомы [6], а применение лучевой терапии сулит пациенту косметически неприемлемые результаты лечения и риск формирования острого и/или хронического лучевого дерматита [7]. Отсутствие на территории нашей страны официнального топического 5-фторурацила делает имиквимод едва ли не единственным терапевтическим методом, разрешенным к применению на территории Российской Федерации, в отношении которого существуют доказательства клинической эффективности у пациентов с базально-клеточным раком кожи [8].
Механизм действия имиквимода при БКК выражается в активации как врожденного, так и приобретенного звена иммунитета [9]. Посредством сигнального каскада toll-подобных рецепторов (TLR-7 и TLR-8) топический имиквимод приводит к секреции провоспалительных цитокинов - интерлейкинов $-1,-6,-10,-12$, фактора некроза опухоли и пр., чем в определенной степени опосредует свое действие [10]. Эфффективность топического имиквимода была подтверждена у пациентов с поверхностными базалиомами кожи.

Целью исследования явилось изучение возможностей дерматоскопии как метода оценки эффективности топического имиквимода у пациентов c БKK.

\section{Материал и методы}

Обследованы 24 пациента (10 мужчин и 14 женщин), страдающих поверхностной формой базально-клеточного рака кожи. Средний возраст пациентов составлял 58,1 \pm 4,2 года. Критериями включения пациентов в исследование были: цитологически и/или гистологически верифицированный диагноз БКК; поверхностная форма БКК (по Lever W., 1958); отсутствие нодулярных элементов опухоли в пределах поверхностного очага, элевирующих более чем на 1 мм от верхнего края поверхностной части БКК; наличие информированного добровольного отказа от иного (альтернативного) медицинского вмешательства (хирургическая эксцизия, электрокоагуляция с (без) кюретажем, лучевая терапия и пр.) или наличие противопоказаний для такого альтернативного вмешательства (анамнестическое указание на различного рода аллергические реакции на местные анестетики и пр.); наличие информированного добровольного согласия на данное медицинское вмешательство (применение топического имиквимода). Критериями исключения пациентов из исследования были: наличие иной клинико-гистологической фрормы БКК (по Lever W., 1958: склеродермоподобной, нодулярной и др.); анамнестическое указание на наличие у пациента экземы, аллергического контактного дерматита или ирритантного дерматита; синдром Горлина - Гольца; пигментная ксеродерма; витилиго или иные заболевания кожи, ассоциированные с де- или гиперпигментацией; особые локализации БКК, не позволяющие применять топический имиквимод (отдельные локализации в области лица, шеи, аногенитальной области); наличие у пациента клинически и/или иммунологически значимой иммуносупрессии (ВИЧ-инфекция и пр.); наличие в процессе лечения выраженной мокнущей экзематизации области применения имиквимода, требующей применения топических глюкокортикостероидов большее число дней в неделю. 
Юридические аспекты исследования: основным правоустанавливающим документом, определяющим право врача-дерматовенеролога устанавливать диагноз и оказывать медицинскую помощь пациентам, страдающим БКК, является приказ Министерства здравоохранения СССР от 21 июля 1988 г. №579 «Об утверждении квалификационных характеристик врачей-специалистов». Данный приказ органа исполнительной власти в сфере здравоохранения действует на территории Российской Федерации без изменений, так как Россия является законной правопреемницей СССР. В соответствии с этими квалификационными характеристиками «... специалист-дерматовенеролог должен уметь установить диагноз и провести все необходимые лечебно-профилактические мероприятия при следующих болезнях: ...опухоли кожи: кератома, базалиома, эпителиома, меланома». Так как приказ Минздрава России от 08.10.2015 №707н не устанавливает иных положений относительно данного раздела гражданского оборота, то при возникновении соответствующих отношений между субъектами (пациентом и медицинской организацией) могут применяться положения приказа Министерства здравоохранения СССР от 21 июля 1988 г. № 579.

На первом этапе, предусмотренном дизайном данного исследования, проводился отбор пациентов с БКК, удовлетворяющих критериям включения. Далее отобранным пациентам с БКК проводилось дерматоскопическое исследование с помощью дерматоскопа Heine delta 20+ (Германия). Фиксация и оценка дерматоскопического изображения осуществлялись с использованием стандартного фотоадаптера Heine и фотоаппарата Canon. Анализ дерматоскопического изображения осуществлялся с помощью описательного языка дерматоскопии (без применения метафорических терминов), установление (подтверждение) дерматоскопического диагноза - с помощью модифицированного анализа паттерна Киттлера. При наличии противопоказаний (аллергия к местным анестезирующим веществам и пр.) и иных ограничений в применении различных хирургических модальностей при БКК пациентам, давшим информированное добровольное согласие на медицинское вмешательство, назначался официнальный оригинальный имиквимод. Топический имиквимод в исследовании назначался пациентам в режиме пять дней в неделю, один раз в сутки. На протяжении всего периода наблюдения пациенты посещали врача-исследователя один раз в месяц. Все пациенты в исследовании случайным образом (методом «конвертов») были разделены на две группы. В 1-й группе $(n=12)$ в качестве критерия эффективности проводимой терапии использовалась дерматоскопия. В этой группе паци- ентов прекращение терапии топическим имиквимодом производилось только после визуально определяемого двумя исследователями исчезновения всех дерматоскопических критериев БКК в очагах и по прошествии с этого момента еще одного месяца. Во 2-й группе $(n=12)$ критерием прекращения медикаментозной терапии имиквимодом являлись клинически определяемые критерии излечения (отсутствие перламутрового блеска поверхности опухоли, выравнивание рельефа дерматоглифики новообразования и пр.) и по прошествии с этого момента еще одного месяца. Чувствительность и специфичность таких суррогатных клинических критериев ответа на терапию имиквимодом, вероятно, были низкими, так как вызываемый имиквимодом ирритантный дерматит способен нивелировать клинические проявления базалиомы в отсутствие факта регресса опухоли. Именно поэтому для потребностей нашего исследования была также установлена минимальная длительность терапии имиквимодом для пациентов 2-й группы, составляющая 5 мес. Такой срок был выбран авторами не случайно, так как является средним по результатам клинических исследований, имевших цель изучить терапевтические возможности имиквимода при различных новообразованиях кожи [11].

После завершения медикаментозной терапии проводилось двукратное патогистологическое исследование очагов базалиомы (первое - через месяц после завершения терапии имиквимодом и топическими глюкокортикостероидами, получаемыми по потребности при наличии выраженного ирритантного дерматита от имиквимода; второе - спустя год после завершения наблюдения для исключения краткосрочных рецидивов опухоли). Для статистической обработки данных использован пакет программ Statistica 8.0. Учитывая отсутствие нормальности распределения полученных результатов, были применены непараметрические методы статистической обработки (в частности, Т-критерий Манна - Уитни и $\chi^{2}$-критерий Пирсона).

\section{Результаты}

Наиболее важным результатом данного исследования явилось получение статистически значимых различий средней длительности терапии топическим имиквимодом в исследуемых группах пациентов $(p=0,05)$. Так, средняя длительность терапии в 1-й группе (дерматоскопический контроль эффективности терапии имиквимодом) составила 12,3 $\pm 1,0$ мес. против 7,4 0,5 мес. в группе клинической оценки эфрфективности лечения. В 1-й группе у всех пациентов без исключения к моменту исчезновения всех дерматоскопических критериев БКК последующее патогистологическое 
исследование инцизионных биоптатов новообразования подтверждало фракт отсутствия опухолевых клеток, т.е. устранение новообразования. Во 2-й группе у 4 пациентов, несмотря на наличие клинических критериев эффективности имиквимода (оцененных двумя независимыми исследователями), при последующем гистологическом исследовании микропрепаратов, полученных из инцизионных биоптатов опухолей, обнаруживались скопления опухолевых базалоидных клеток. Этот фракт указывает на недостаточную продолжительность лечения в том случае, если врач при оценке длительности терапии имиквимодом опирается исключительно на клинические, т.е. определяемые невооруженным глазом критерии эфффективности лечения БКК. У упомянутых четырех пациентов ретроспективно были оценены результаты проведенной одновременно с инцизионной биопсией дерматоскопии. При этом у всех четырех пациентов были выявлены дерматоскопические признаки БКК (серо-синие комки и пр.).

В результате исследования показано, что у пациентов 1-й группы под воздействием имиквимода различные дерматоскопические структуры поверхностной БКК регрессировали неравномерно. Так, первыми дерматоскопическими структурами, которые регрессировали раньше других, были разветвленные сосуды, их средний период полного регресса составлял 2,1 \pm 0,2 месяца, затем регрессировали тонкие серпантинные сосуды 2,5 \pm 0,6 мес. Средний период регресса бесструктурных областей телесного, белого, светло-коричневого цвета составлял 4,7 $\pm 1,1$ мес., радиальных коричневых линий, расположенных центрально или по периферии, соединенных общим основанием (точкой или комком), - 6,8 \pm 0,9 мес. Дерматоскопическими структурами, которые регрессировали последними, были серо-голубые комки, их период окончательного регресса соответствовал сроку констатации выздоровления и составлял $11,3 \pm 1,2$ месяца. Значение $p>0,05$ (для указанных средних величин) определялось малым объемом клинических групп.

После года наблюдения всем пациентам была произведена контрольная инцизионная биопсия из мест, выбранных под контролем дерматоскопии. Для оценки полученных результатов был применен $\chi^{2}$-критерий Пирсона для таблиц сопряженности. Выявлены статистически значимые различия с высоким уровнем достоверности ( $\chi^{2}$-критерий равен 4,6, р < 0,05). Среди пациентов 1-й группы $(n=12)$ не было зарегистрировано ни одного рецидива БКК. Среди пациентов 2-й группы ( $n=8$, так как четырем пациентам эксцизия была произведена при констатации рецидива ранее) рецидив БКК был зарегистрирован спустя год наблюдения у всех пациентов. Причем этот рецидив не проявлялся клинически, а характеризовался только дерматоскопическими признаками: появлением бесструктурной зоны телесного цвета (светло-коричневой), тонких серпантинных и разветвленных кровеносных сосудов, одиночных серо-синих точек, редко комков $(n=2)$.

\section{Обсуждение}

Несмотря на относительно небольшой объем выборки пациентов, в исследовании было продемонстрировано, что клинические характеристики очага, вероятно, являются плохим критерием эффективности терапии топическим имиквимодом. Для окончательного подтверждения данного предположения необходимы более крупные клинические проспективные исследования. Тем не менее наше исследование продемонстрировало возможности дерматоскопии как способа оценки эффективности терапии имиквимодом у пациентов с БКК. Перспективы использования дерматоскопии с этой целью позволят значительно уменьшить частоту рецидивов БКК после терапии имиквимодом. Наиболее важным результатом настоящего исследования явилось понимание того, что различные дерматоскопические структуры в поверхностных БКК на фоне терапии имиквимодом регрессируют последовательно в различные сроки. Наиболее ранними структурами, регрессирующими в опухоли, являются разветвленные и серпантинные кровеносные сосуды. Степень опухолевого неоангиогенеза, как правило, зависит от профиля цитокинов, выделяемых опухолевыми клетками. Кровеносные сосуды, по понятным причинам, являются статичными структурами любого новообразования, в том числе БКК, поэтому такая «эфемерность» на дерматоскопическом изображении в динамике лечения имиквимодом вызывает большие вопросы. По нашему мнению, их «исчезновение» на первых этапах терапии может являться лишь оптическим феноменом, возникающим из-за формирования ирритантного дерматита, сопровождающегося значительным акантозом, спонгиозом и периваскулярной полиморфно-клеточной инфильтрацией, что может скрывать за собой иные дерматоскопические феномены. Аналогичная ситуация, вероятно, имеет место и в отношении бесструктурных областей белого и телесного цвета. Патоморфологическим субстратом последних является фриброз межклеточного вещества стромы опухоли. Таким образом, исчезновение данных дерматоскопических структур, во-первых, не является важным элементом оценки эффективности терапии имиквимодом, а, во-вторых, вероятно, является таким же оптическим феноменом, связанным с формированием ирритантного дерматита в месте нанесения 
препарата. Что же касается остальных дерматоскопических структур (серые, синие и коричневые точки и комки, коричневые радиальные линии, соединенные общим основанием), то скорость их регресса зависела от размера структуры (вначале точки, затем радиальные линии, исходящие из общего основания, затем комки) и цвета пигмента (вначале коричневые, затем серые, затем синие). Нетрудно догадаться, что синие крупные комки регрессировали на дерматоскопических изображениях в последнюю очередь. Таким образом, именно их исчезновение на дерматоскопическом изображении знаменует полный регресс поверхностно распространенной БКК.

Обсуждая результаты настоящего исследования, нельзя не остановиться на одном очень важном нюансе. Наличие на дерматоскопическом изображении отдельно взятой поверхностной БКК, одной или нескольких пигментных структур, таких как, например, синие комки или серые точки, не делает эту базалиому пигментной (по Lever W., 1958), так как данные структуры чаще всего не определяются клинически и располагаются в большинстве поверхностных БКК. В нашей выборке пациентов у всех 24 больных выявлялись те или иные пигментные дерматоскопические структуры. Но при их отсутствии в поверхностной БКК оценить эффективность топического имиквимода с помощью дерматоскопии, по понятным причинам, практически не представляется возможным. В таких ситуациях врач вынужден опираться либо на суррогатные клинические характеристики регресса, либо на данные, полученные в результате иных крупных рандомизированных исследований.

В заключение приведем наиболее яркое клиническое наблюдение из нашей серии. Пациент 79 лет, страдает очагом поверхностной БКК на протяжении нескольких лет. Включен в исследование по причине категорического нежелания проводить радикальное оперативное лечение клинически и дерматоскопически очевидной БКК. Пациенту был назначен топический имиквимод (рис. 1). Спустя 6 мес. терапии наступило клиническое выздоровление и дерматоскопическое улучшение (рис. 2). Спустя 11 мес. терапии отмечен полный регресс дерматоскопических признаков БКК (клинически в центральной зоне очага определяется круста, образовавшаяся после проведенной инцизионной биопсии очага) (рис. 3). На рис. 4, 8, 12 представлена последовательная динамика дерматоскопической картины зоны 1, отмеченной на рис. 1 , на рис. 5, 9, 13 - динамика зоны 2, на рис. $6,10,14-$ зоны 3 , на рис. 7,11 , 15 - зоны 4.

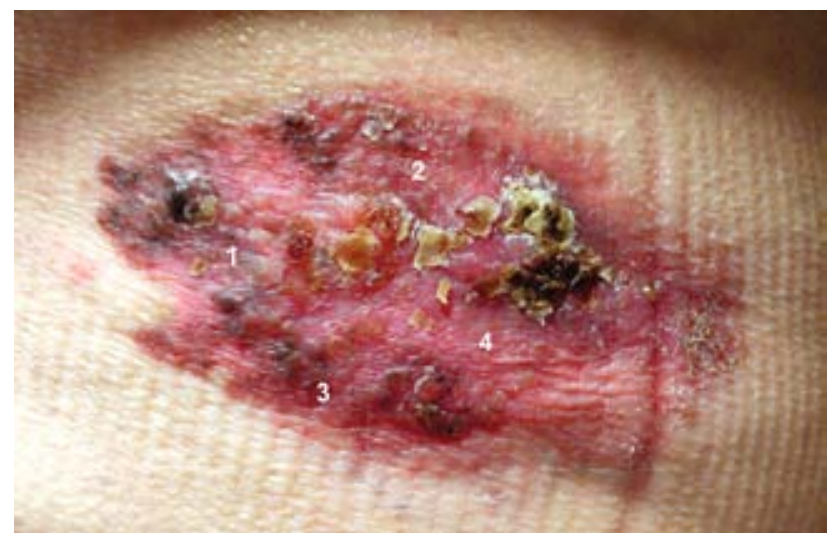

Рис. 1. Клиническое изображение (до начала терапии имиквимодом) с распределением по дерматоскопическим зонам



Рис. 2. Клиническое изображение (6 месяцев от начала терапии имиквимодом)

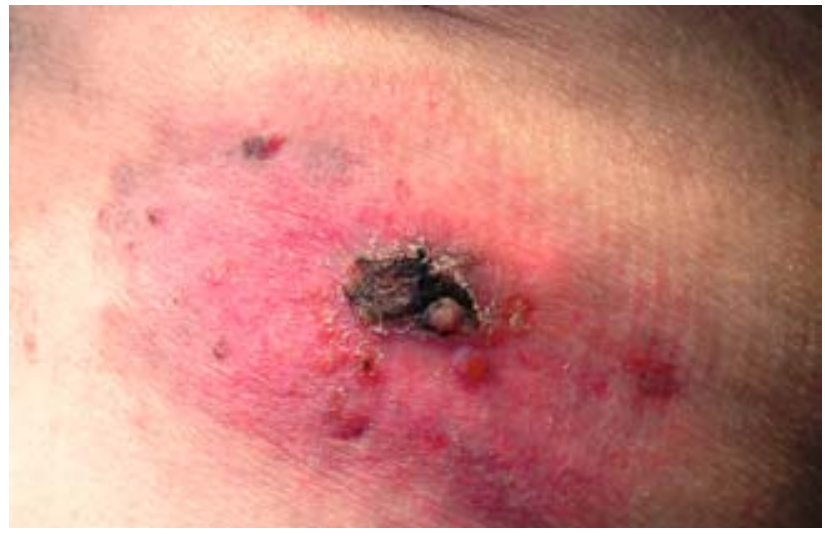

Рис. 3. Клиническое изображение (11 месяцев от начала терапии имиквимодом) 


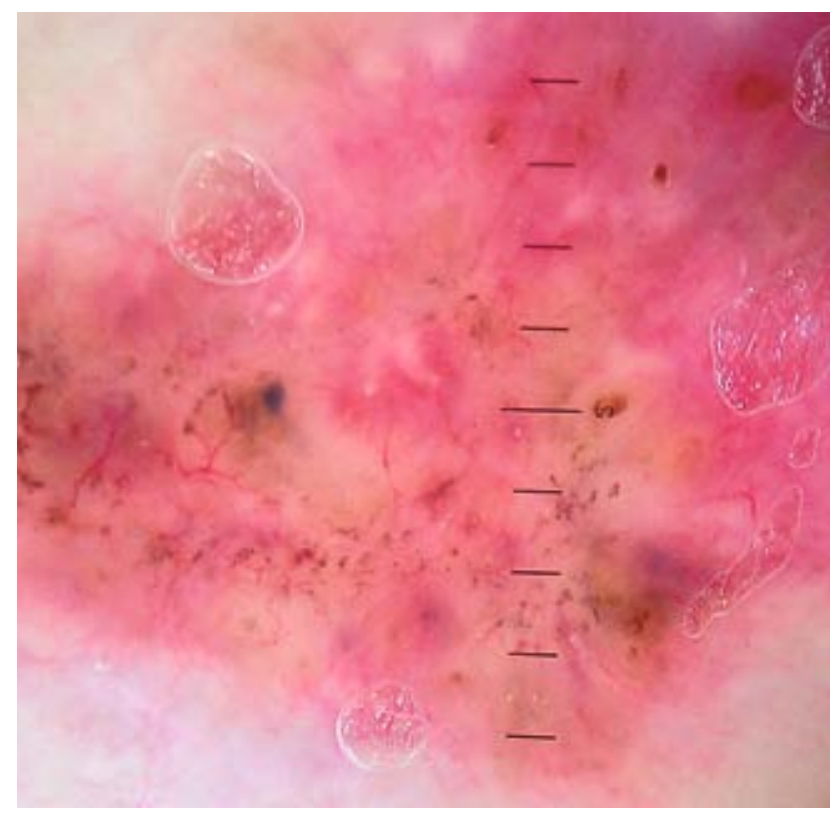

Рис. 4. Дерматоскопическое изображение, зона № 1 (до начала терапии имиквимодом)

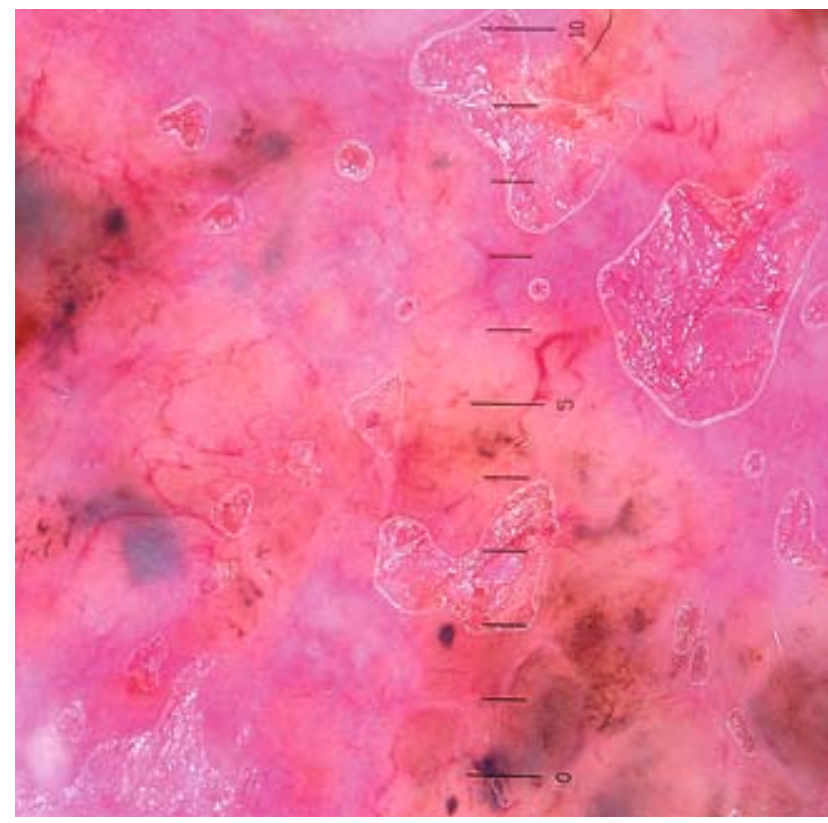

Рис. 5. Дерматоскопическое изображение, зона №2 (до начала терапии имиквимодом)

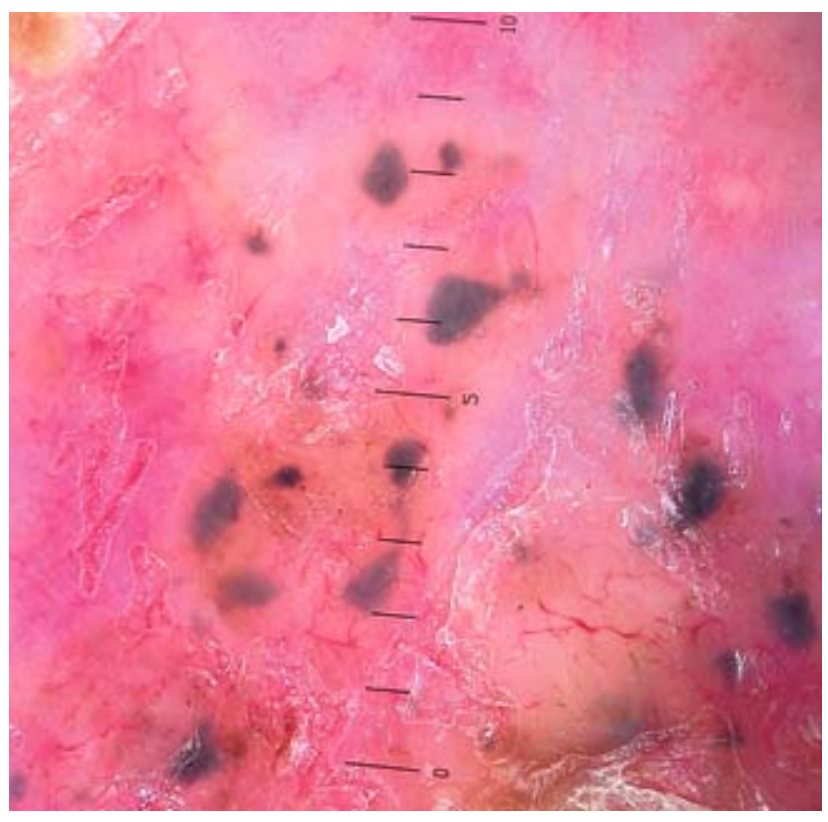

Рис. 6. Дерматоскопическое изображение, зона №3 (до начала терапии имиквимодом)

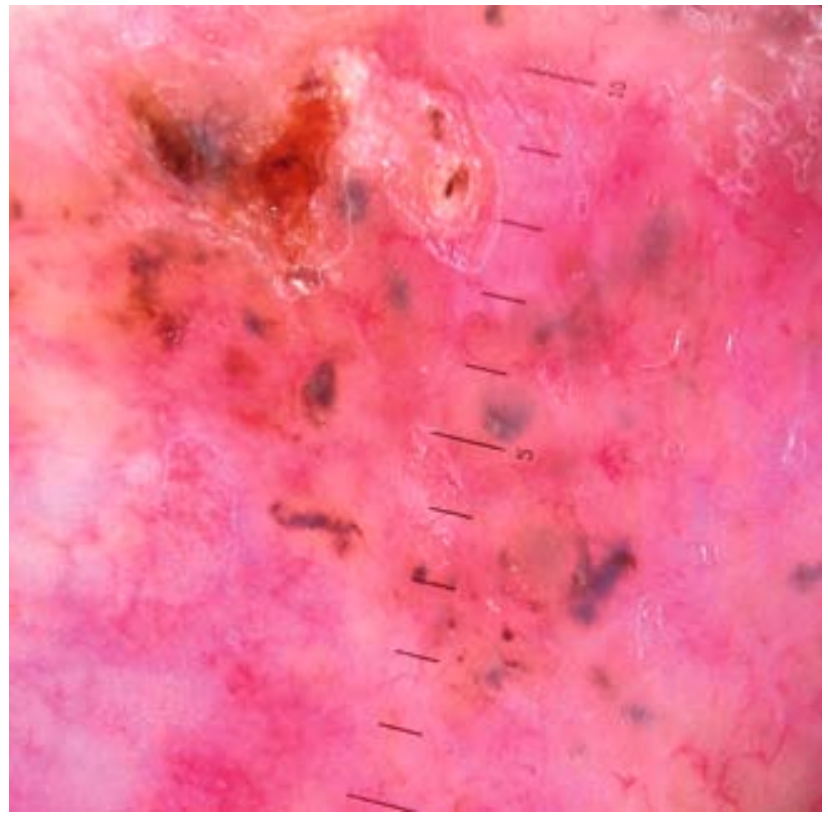

Рис. 7. Дерматоскопическое изображение, зона № 4 (до начала терапии имиквимодОМ) 


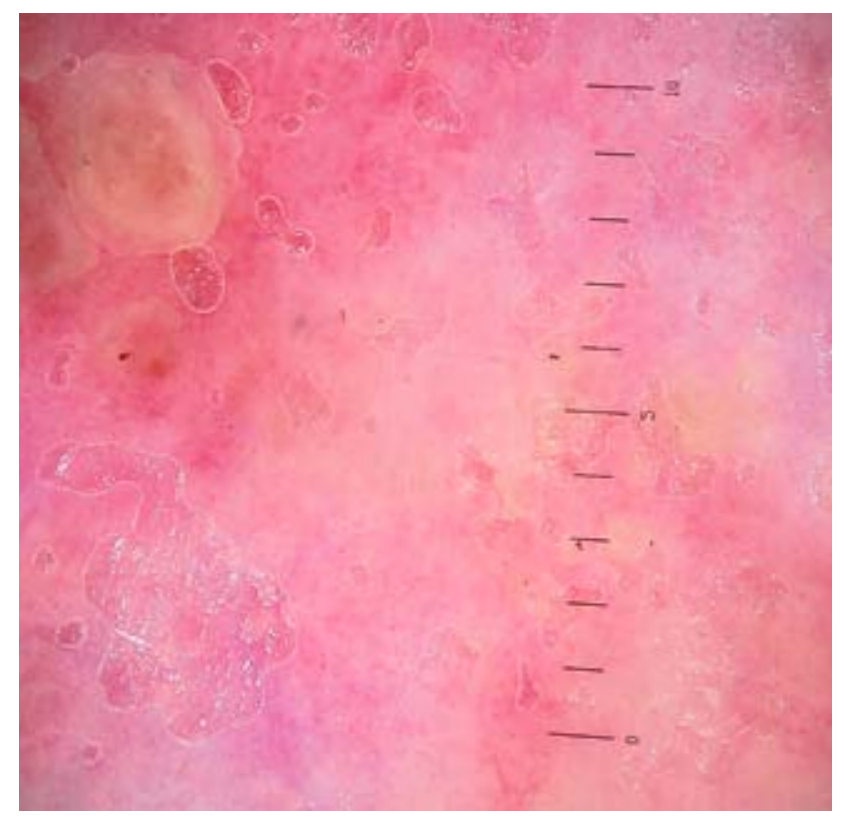

Рис. 8. Дерматоскопическое изображение, зона № 1 (6 месяцев от начала терапии имиквимодом)

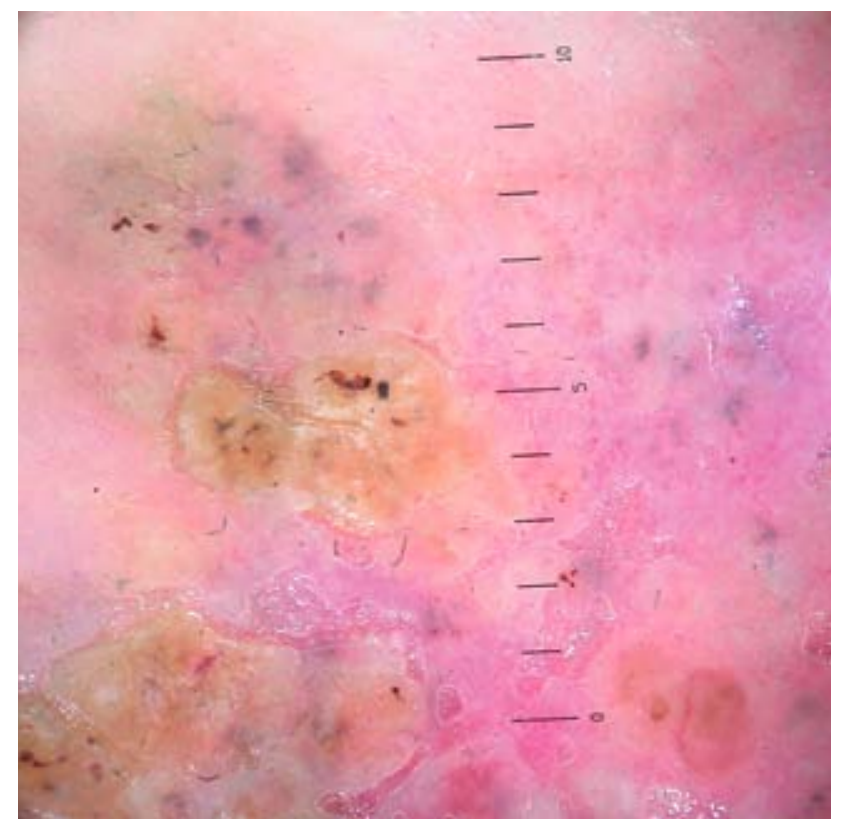

Рис. 9. Дерматоскопическое изображение, зона №2 (6 месяцев от начала терапии имиквимодом)

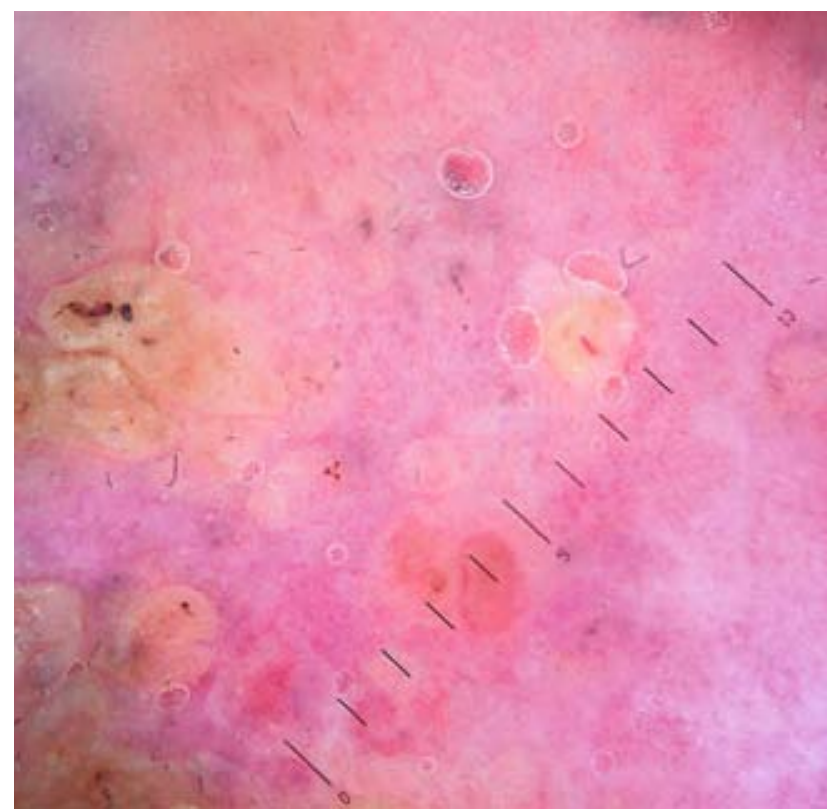

Рис. 10. Дерматоскопическое изображение, зона № 3 (6 месяцев от начала терапии имиквимодом)

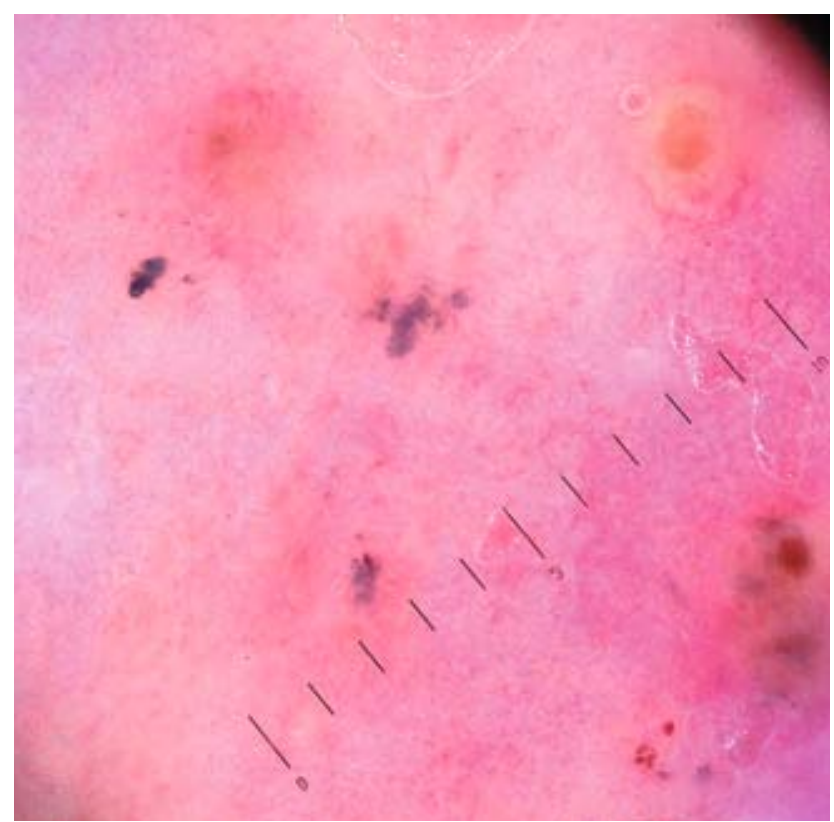

Рис. 11. Дерматоскопическое изображение, зона №4 (6 месяцев от начала терапии имиквимодом) 


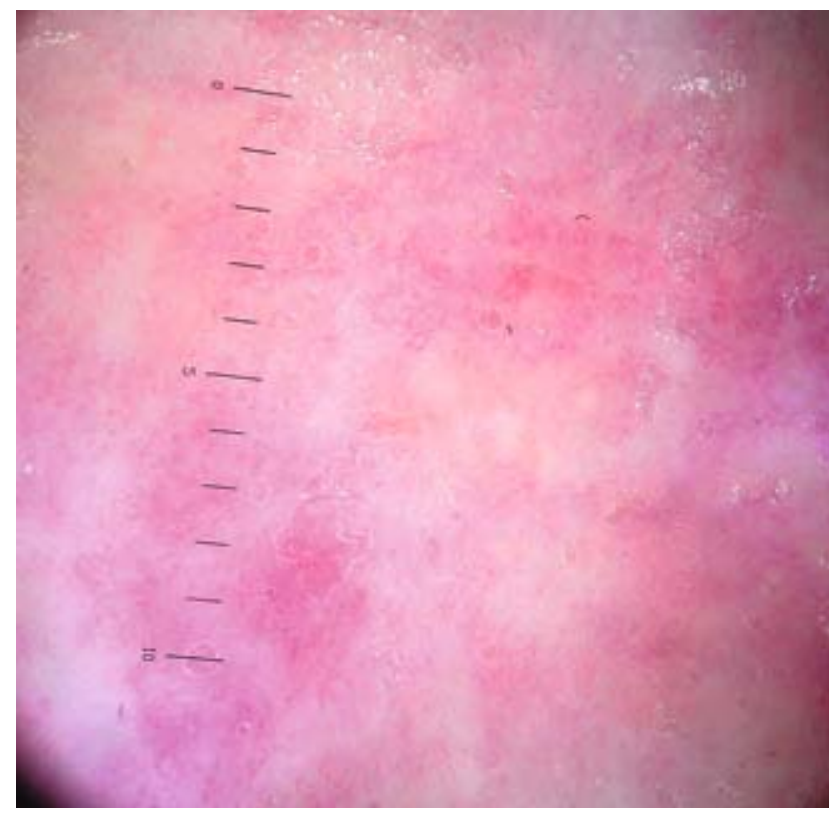

Рис. 12. Дерматоскопическое изображение, зона № 1 (11 месяцев от начала терапии имиквимодом)

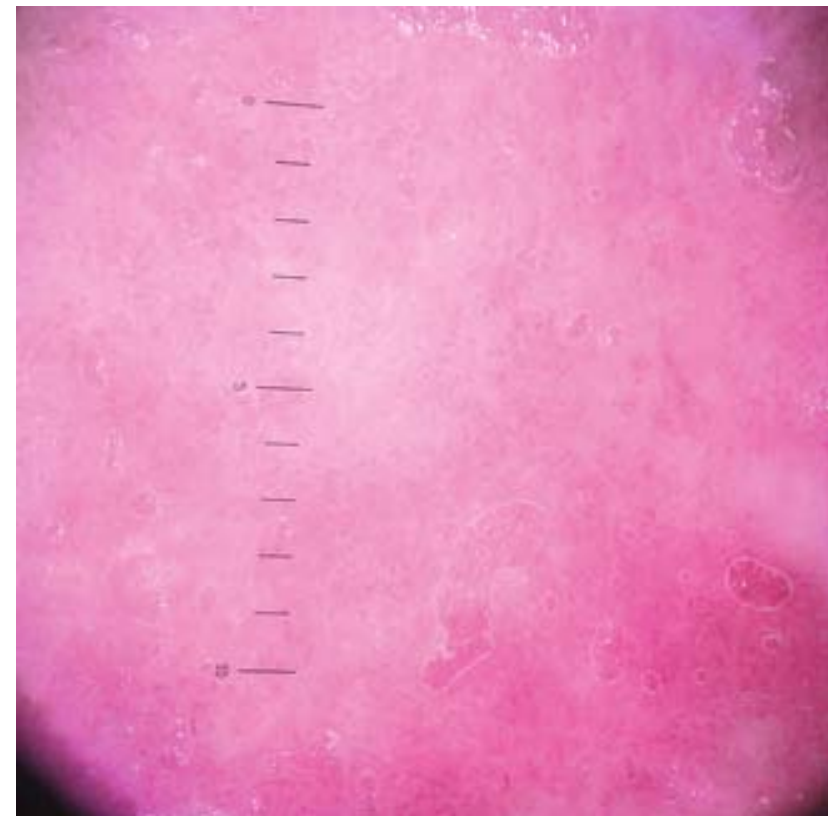

Рис. 13. Дерматоскопическое изображение, зона №2 (11 месяцев от начала терапии имиквимодом)

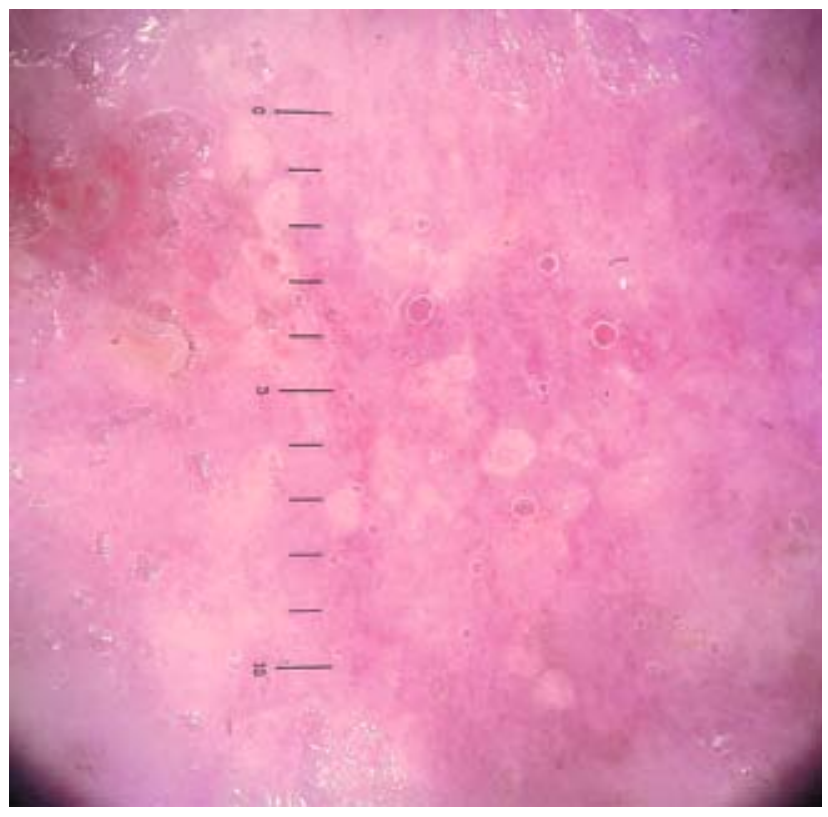

Рис. 14. Дерматоскопическое изображение, зона №3 (11 месяцев от начала терапии имиквимодом)

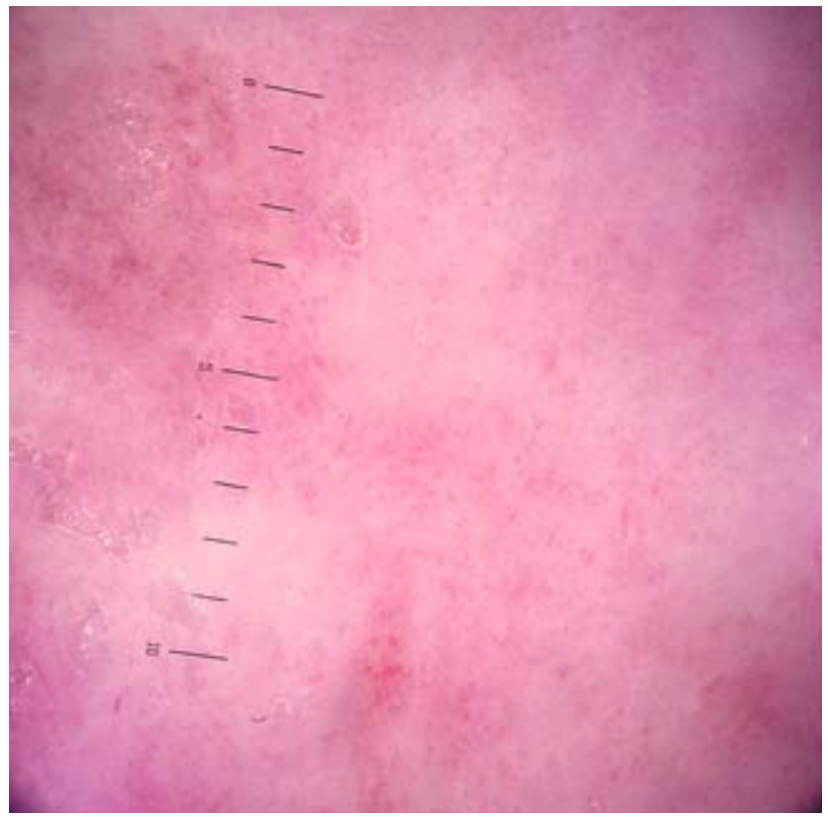

Рис. 15. Дерматоскопическое изображение, зона №4 (11 месяцев от начала терапии имиквимодом) 


\section{Выводы}

В настоящем исследовании продемонстрирована эффрективность дерматоскопии как метода оценки результативности терапии топическим имиквимодом при поверхностных БКК. Продемонстрирована большая прогностическая значимость дерматоскопии по срав- нению с простым клиническим осмотром образования при оценке момента прекращения медикаментозной терапии в данной клинической ситуации. Показаны средние сроки регресса различных дерматоскопических признаков базалиомы на фоне терапии имиквимодом.

\section{Литература}

1. Lubeek S.F. et al. The Epidemiology and Clinicopathological Features of Basal Cell Carcinoma in Patients 80 Years and Older: A Systematic Review. JAMA Dermatol. 2017 Jan 1; 153 (1): 71-78.

2. Hogan D.J., To T., Gran L., Wong D., Lane P. R. Risk factors for basal cell carcinoma. Int J Dermatol 1989 Nov; 28 (9): 591—594.

3. Silapunt S., Chen L., Migden M. R. Hedgehog pathway inhibition in advanced basal cell carcinoma: latest evidence and clinical usefulness. Ther Adv Med Oncol 2016 Sep; 8 (5): 375—82.

4. Ceilley R. I., Del Rosso J. Q. Current modalities and new advances in the treatment of basal cell carcinoma. Int J Dermatol 2006 May; 45 (5): 489-98.
5. Gniadecki R. et al. Favourable results of Mohs micrographic surgery for basal cell carcinoma. Dan Med J 2015 Dec; 62 (12): A5171.

6 . Zou Y. et al. Photodynamic therapy versus surgical excision to basal cell carcinoma: metaanalysis. J Cosmet Dermatol 2016 Dec; 15 (4): 374-382.

7. Piccinno R. et al. Dermatologic radiotherapy in the treatment of extensive basal cell carcinomas: a retrospective study. J Dermatolog Treat 2017 Jan 29: 1-5.

8. Graells J., Ojeda R.M., García-Cruz A. Effect of imiquimod as compared with surgery on the cancerization field in basal cell carcinoma. Actas Dermosifiliogr. 2014 Jan-Feb; 105 (1): 53—9.
9. Soong R.S. et al. Toll-like receptor agonist imiquimod facilitates antigen-specific CD8+ T-cell accumulation in the genital tract leading to tumor control through IFN $\gamma$. Clin Cancer Res 2014 Nov 1; 20 (21): 5456-5467.

10. Telò I. et al. Mechanisms of imiquimod skin penetration. Int J Pharm 2016 Sep 10; 511 (1): 516-523.

11. Kaçar S. D., Özuğuz P., Erkan F., Karaca Ş. Treatment of various types of basal cell carcinoma with topical $5 \%$ imiquimod in the elderly who refused surgical intervention: a case series. J Dermatolog Treat 2015 Apr; 26 (2): 165—167.

об авторах:

М. В. Жучков - врач-дерматовенеролог, зам. главного врача ГБУ РО «Областной клинический кожно-венерологический диспансер», ассистент кафедры сестринского дела ФГБОУ ВО РязГМУ Минздрава России

Д. Б. Сонин - к.м.н., зам. главного врача ГБУ РО «Областной клинический кожно-венерологический диспансер», Рязань М. А. Тарасова — к.м.Н., главный врач ГБУ РО «Областной клинический кожно-венерологический диспансер», ассистент кафедры дерматовенерологии ФГБОУ ВО РязГМУ Минздрава России

С. А. Косорукова — врач-дерматовенеролог, к.м.Н., ассистент кафедры дерматовенерологии ФГБоУ ВО РязГМУ Минздрава России

\section{Конфликт интересов}

Авторы заявляют об отсутствии потенциального конфликта интересов, требующего раскрытия в данной статье 